\title{
Bariosincosite, a new hydrated barium vanadium phosphate, from the Spring Creek Mine, South Australia
}

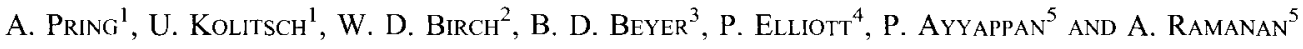 \\ ${ }^{1}$ Department of Mineralogy, South Australian Museum, North Terrace, Adelaide, South Australia 5000, Australia \\ ${ }^{2}$ Department of Mineralogy, Museum of Victoria, P.O. Box 666E, Melbourne, Victoria 3001, Australia \\ ${ }^{3}$ P.O. Box 33, Laura, South Australia 5480, Australia \\ ${ }^{4}$ Post Office, Carey Gully, South Australia 5144, Australia \\ ${ }^{5}$ Department of Chemistry, Indian Institute of Technology, New Delhi, 110016 India
}

\section{ABSTRACT}

Bariosincosite is a new barium vanadium phosphate hydrate from the Spring Creek Mine, near Wilmington, South Australia. The new mineral occurs as irregular clusters of pale green, very thin platey crystals up to $250 \mu \mathrm{m}$ across and 2 to $5 \mu \mathrm{m}$ thick. The tetragonal crystals are tabular on $\{001\}$ and the other form present is $\{100\}$. Associated with bariosincosite are quartz, cuprite, native copper, fluorapatite, whitlockite, baryte and springcreekite, $\mathrm{BaV}_{3}^{3+}\left(\mathrm{PO}_{4}\right)_{2}\left(\mathrm{OH}, \mathrm{H}_{2} \mathrm{O}\right)_{6}$. Bariosincosite appears to have formed under supergene or low-temperature late-stage hydrothermal conditions. Electron microprobe analysis yielded: $\mathrm{BaO} 23.20$; $\mathrm{SrO} 4.19 ; \mathrm{CaO} 0.36 ; \mathrm{VO}_{2} 31.55 ; \mathrm{Fe}_{2} \mathrm{O}_{3} 0.20 ; \mathrm{Al}_{2} \mathrm{O}_{3} 0.50$; $\mathrm{P}_{2} \mathrm{O}_{5} 28.15 ; \quad \mathrm{H}_{2} \mathrm{O} 13.93$ (calculated). These data give an empirical formula of $\left(\mathrm{Ba}_{0.77} \mathrm{Sr}_{0.20} \mathrm{Ca}_{0.03}\right)_{\Sigma 1.00}\left[\left(\mathrm{~V}_{0.96}^{4+} \mathrm{Al}_{0.03} \mathrm{Fe}_{0.01}^{3+}\right)_{\Sigma 1.00} \mathrm{O}\left(\mathrm{PO}_{4}\right)\right]_{2} \cdot 4 \mathrm{H}_{2} \mathrm{O}$, calculated on the basis of two $\mathrm{P}$ atoms. The simplified formula is $\mathrm{Ba}\left(\mathrm{V}^{4+} \mathrm{OPO}_{4}\right)_{2} \cdot 4 \mathrm{H}_{2} \mathrm{O}$. The mineral is transparent with a very pale green streak, a vitreous lustre and an estimated Mohs hardness of 3. The strongest lines in the X-ray powder pattern are $\left[d_{\text {obs }}\left(I_{\text {obs }}\right)(h k l)\right] 6.414(20)(110,002) ; 5.748(70)(111) ; 4.552(30)(112,200)$; 3.198 (20) (220, 004); 3.100 (100) (203, 221); 2.847 (40) (222, 114); 2.786 (80) (311); 2.368 (30) $(313,115)$; and $2.017(100)(420,332,116)$. These data were indexed on a tetragonal cell, with $a=9.031(6), c=12.755(8) \AA$ and $V=1040(1) \AA^{3}$; the space group is probably $P 4 / n$ or $P 4 / n m m$. For $Z=4$ and using the empirical formula, the calculated density is $3.306 \mathrm{gm} / \mathrm{cm}^{3}$. Bariosincosite is uniaxial negative with $\omega=1.721(2)$ and $\varepsilon=1.715(2)$ (white light); pleochroism is weak from colourless $(\mathrm{E})$ to pale green $(\mathrm{O})$, absorption $\mathrm{O}>\mathrm{E}$. The mineral is named for the relationship to sincosite, $\mathrm{Ca}\left(\mathrm{V}^{4+} \mathrm{OPO}_{4}\right)_{2} \cdot 4 \mathrm{H}_{2} \mathrm{O}$.

Kerwords: bariosincosite, new mineral, barium vanadium phosphate, sincosite, Spring Creek Mine, South Australia.

\section{Introduction}

THE Spring Creek Mine exploited a small copper deposit near Wilmington, at the southern end of the Flinders Ranges, South Australia. The small mine dumps have yielded a rich suite of secondary minerals, including a number of rare phosphates such as beraunite, chalcosiderite, hentschelite, mitridatite and perloffite (Birch and Mumme, 1988, Beyer and Elliott, 1996). During extensive investigations of the mineralogy of the deposit,
Beyer and Elliott (1996) noted two unknown barium vanadium phosphate minerals. The characterization and description of one of these species, the $\mathrm{Ba}$ analogue of sincosite, is the subject of this paper. The new species, bariosincosite, has been named for its relationship to sincosite, $\mathrm{Ca}\left(\mathrm{VOPO}_{4}\right)_{2}-4 \mathrm{H}_{2} \mathrm{O}$. The mineral and the name were approved by the Commission on New Minerals and Mineral Names in 1998 (98-047). The type specimen is held in the collections of the South Australian Museum, Adelaide.

(c) 1999 The Mineralogical Society 


\section{Occurrence}

The Spring Creek Mine $\left(32^{\circ} 41^{\prime} \mathrm{S} 137^{\circ} 07^{\prime} \mathrm{E}\right)$ is situated $\sim 10 \mathrm{~km}$ south of Wilmington and on the eastern flank of Mt Remarkable, at the southern end of the Flinders Ranges, South Australia. The copper deposit was discovered in 1860 (Austin, 1863) and was worked intermittently for its rich cuprite-native copper-bearing ore. Work was finally abandoned in 1918 and the mine was reserved from the operation of the mining act to allow for it to be used as a water supply for the nearby township of Wilmington. In 1996 the Spring Creek Mine and the surrounding area was transferred to the Mt Remarkable National Park and collection of material is now prohibited.

The Spring Creek copper deposit is located within the contact zone of a quartzite unit of the Rhynie Sandstone group and a slate unit of the Tindelpina Shale (part of the Tapley Hill formation), both units being members of the late Proterozoic Adelaide System. The copper mineralization occurs as two intersecting lodes in a fault zone. This zone is severely fractured and has been the locus for copper enrichment (Binks et al., 1968; Preiss, 1987). The mine water is not acidic, indicating the absence of primary sulphides beneath the ore zone and suggesting that the copper may have been transported some distance from its primary source (Jack, 1917). Some small phosphate deposits in the region are also associated with rocks of the Tapley Hill formation, this formation could be the source of the phosphate mineralization at Spring Creek (Summers, 1953, Beyer and Elliott, 1996). Cuprite, the principal copper mineral, and the secondary phosphates occur in vugs and cavities in the quartz-goethite matrix.

The new mineral generally occurs as irregular clusters of very thin platey crystals on the faces of slightly corroded cuprite crystals within cavities in a quartz-goethite matrix. On one specimen, the mineral occurs on native copper. The associated minerals are quartz, native copper, fluorapatite, whitlockite, baryte and springcreekite, $\mathrm{BaV}_{3}^{3+}\left(\mathrm{PO}_{4}\right)_{2}\left(\mathrm{OH}, \mathrm{H}_{2} \mathrm{O}\right)_{6}$ (Kolitsch and Pring, 1999). Bariosincosite appears to have formed under supergene or low-temperature late-stage hydrothermal conditions. The close association with cuprite and native copper indicates a slightly oxidizing or neutral environment (Williams, 1990). It is a late-stage secondary mineral which appears to predate only springcreekite in the paragenetic sequence. There is some evidence of subsequent remobilization of fluorapatite and quartz, as tiny crystal of these minerals, together with crystals of springcreekite, occur on the surface of some of the bariosincosite crystals.

\section{Physical and optical properties}

Bariosincosite occurs as irregular, radiating to divergent groups of platey crystals up to $250 \mu \mathrm{m}$ square and $5 \mu \mathrm{m}$ thick. The principal form observed is $\{001\}$ and the SEM image shows that the only other form is $\{100\}$ (Fig. 1). Possible twinning on $\{110\}$ was observed during the SEM investigation and the crystals often exhibit subparallel growth of $\{001\}$. The crystals have a splintery fracture and a distinct cleavage on $\{001\}$. They are transparent and the colour is pale green with a slightly bluish tinge (No. 134D on the Royal Horticultural Society, London, colour chart); the streak is very pale green. The lustre is vitreous and the Mohs hardness is estimated to be 3 , based on a test on synthetic $\mathrm{Ba}\left(\mathrm{VOPO}_{4}\right)_{2} \cdot 4 \mathrm{H}_{2} \mathrm{O}$. The density could not be measured because of the very thin nature of the crystals; the calculated density, based on the empirical formula and with $Z=4$, is $3.306 \mathrm{~g} \mathrm{~cm}^{-3}$, or $3.40 \mathrm{~g} \mathrm{~cm}^{-3}$ for the simplified formula $\mathrm{Ba}\left(\mathrm{VOPO}_{4}\right)_{2} \cdot 4 \mathrm{H}_{2} \mathrm{O}$.

The optical parameters of bariosincosite were determined in white light using Cargille immersion liquids. The mineral is uniaxial negative with $\omega=1.721(2)$ and $\varepsilon=1.715(2)$. However, because of the small crystal size, the extreme thinness of the crystals and the unavoidable, close intergrowth of subparallel plates, it can not be ruled

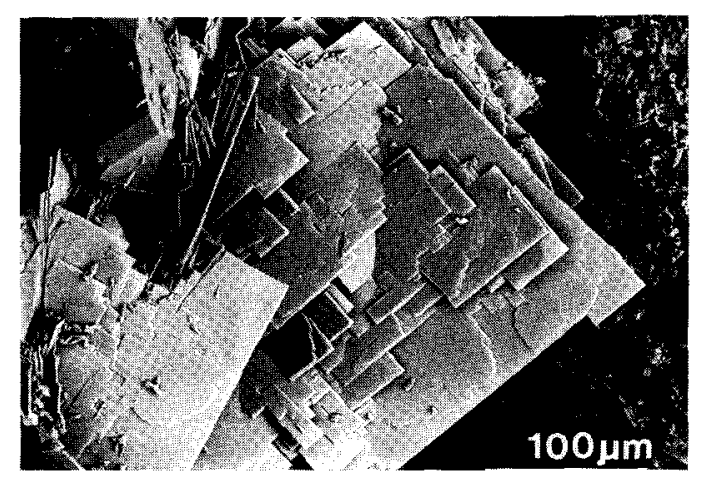

FIG. 1. SEM photomicrograph showing a group of platey bäriosincosite crystals. 
out that bariosincosite may be biaxial with a very small optical angle. The latter possibility might be suggested by the interference colours which were found to be anomalous bluish grey; however, a dispersion of the optical axes was not observed. Pleochroism is weak, E colourless and $\mathrm{O}$ pale greenish, and absorption $\mathrm{O}>\mathrm{E}$. Extinction is straight both along the plate edges and parallel to $\{001\}$.

For the purposes of comparison, the optical properties of monoclinic (pseudotetragonal) synthetic $\mathrm{Ba}\left(\mathrm{VOPO}_{4}\right)_{2} \cdot 4 \mathrm{H}_{2} \mathrm{O}$ were also investigated using the same method. The crystals are biaxial negative, with $\alpha 1.716(2), \beta$ 1.722(2), $\gamma$ 1.722(2). The difference between $\beta$ and $\gamma$ is estimated to be $0.0005 .2 \mathrm{~V}$ (est.) is $\sim 50 \pm 10$ and dispersion is strong, $r>v$. The interference colours are anomalous bluish grey and the optical axis plane is parallel to $\{100\}_{\text {tct }}$. Unlike the mineral from the Spring Creek Mine, the extinction is oblique and the angle between plate edges and the extinction position is $13.3 \pm 0.5$; plates sitting on their edges show straight extinction. The synthetic material also shows prominent twinning on $\{110\}_{\text {tet }}$ which was only rarely observed in the natural material.

\section{Chemistry}

Bariosincosite was analysed using a Cameca SX50 electron microprobe at $15 \mathrm{kV}$ with a nominal specimen current of $0.02 \mu \mathrm{A}$. The standards used were pure $\mathrm{V}$ metal, benitoite (Ba), celestite ( $\mathrm{Sr})$, wollastonite (Ca), fluorapatite $(\mathrm{P})$, hematite $(\mathrm{Fe})$ and corundum $(\mathrm{Al})$. Traces of $\mathrm{Cu}$ were also detected. As water could not be determined directly due to insufficient material, in the analyses below water was calculated to give $4 \mathrm{H}_{2} \mathrm{O}$ by analogy with sincosite. Initial electron microprobe analyses gave low totals $(\sim 90 \%)$ but remarkably accurate cation ratios. In order to overcome this problem, thin crystals of natural sincosite (of known composition and similar thickness) were used as a secondary standard and the analysis totals were corrected for the effects of beam penetration through the crystals. The final analyses leave little doubt that the mineral is chemically the $\mathrm{Ba}$ analogue of sincosite (Table 1). Some variation in the ratio of $\mathrm{Ba}: \mathrm{Sr}$ was noted in the analyses. Eight additional partial analyses were undertaken in order to monitor the distribution of $\mathrm{Ba}$ and $\mathrm{Sr}$. Although their distribution was found to be somewhat heterogeneous and varying from $7.5: 1$ to $1.6: 1$, in all of the crystals analysed $\mathrm{Ba}$ was dominant over $\mathrm{Sr}$. The empirical formula, calculated on the basis of $2 \mathrm{P}$ atoms, is $\left(\mathrm{Ba}_{0.77} \mathrm{Sr}_{0.20} \mathrm{Ca}_{0.03}\right)_{\Sigma 1.00}$ $\left[\left(\mathrm{V}_{0.96}^{4+} \mathrm{Al}_{0.03} \mathrm{Fe}_{0.01}^{3+}\right)_{\Sigma 1.00} \mathrm{O}\left(\mathrm{PO}_{4}\right)\right]_{2} \cdot 4 \mathrm{H}_{2} \mathrm{O}$, and the simplified formula is $\mathrm{Ba}\left(\mathrm{V}^{4+} \mathrm{OPO}_{4}\right)_{2} \cdot 4 \mathrm{H}_{2} \mathrm{O}$.

\section{X-ray crystallography}

The X-ray powder diffraction pattern was recorded using a $100 \mathrm{~mm}$ diameter GuinierHägg camera with monochromated $\mathrm{Cr}-K \alpha_{1}$ radiation $(\lambda=2.2896 \AA)$ and with silicon employed as an internal standard. Line intensities were estimated visually by comparison with a set of standard reflections. Because reflections with $d$-spacings of $<2 \AA$ tend to be faint and difficult to measure on films recorded using $\mathrm{Cr}-K \alpha_{1}$ radiation, a second powder pattern was recorded using a $114.6 \mathrm{~mm}$ diameter Gandolfi camera with Co- $K \alpha$ radiation $(\lambda=1.79021 \AA)$. The powder patterns for bariosincosite are given in Table 2 . The patterns were indexed on the basis of a tetragonal cell similar to that given for sincosite by Zolensky (1985). Least-squares refinement of the cell using the Guinier-Hägg pattern gave a tetragonal unit cell with $a=9.031(6)$, $c=12.755(8) \AA, V=1040(1) \AA^{3}$. The axial ratio calculated from the unit cell parameters $c: a$ is $1.412: 1$. Attempts were also made to index the pattern on the basis of the monoclinic unit cell for synthetic $\mathrm{Ba}\left(\mathrm{VOPO}_{4}\right)_{2} \cdot 4 \mathrm{H}_{2} \mathrm{O}$ given by Roca et al. (1997); however, this gave a cell with higher

TABLE 1. Electron microprobe analysis of bariosincosite (wt.\%)

\begin{tabular}{lcrc}
\hline Constituent & Range & Mean & Atoms $^{3}$ \\
\hline $\mathrm{BaO}$ & $17.72-26.80$ & 23.20 & 0.77 \\
$\mathrm{SrO}$ & $2.41-7.49$ & 4.19 & 0.20 \\
$\mathrm{CaO}$ & $0.17-0.60$ & 0.36 & 0.03 \\
$\mathrm{VO}_{2}$ & $30.71-32.46$ & 31.55 & 1.92 \\
$\mathrm{Fe}_{2} \mathrm{O}_{3}$ & $0.15-0.23$ & 0.20 & 0.01 \\
$\mathrm{Al}_{2} \mathrm{O}_{3}$ & $0.35-0.62$ & 0.50 & 0.06 \\
$\mathrm{P}_{2} \mathrm{O}_{5}$ & $27.26-29.18$ & 28.15 & 2.00 \\
$\mathrm{H}_{2} \mathrm{O}$ & & $13.93^{1}$ & \\
Total & & $102.08^{2}$ & \\
& & & \\
\hline
\end{tabular}

1. Water calculated on the basis of $4 \mathrm{H}_{2} \mathrm{O}$ per formula unit.

2. High total due to dehydration in the beam

3. Calculated on the basis of $2 \mathrm{P}$ atoms

No other elements with $Z>8$ were detected 


\section{A. PRING ETAL}

TABLE 2. X-ray powder diffraction data for bariosincosite $\mathrm{Ba}\left(\mathrm{VOPO}_{4}\right)_{2} \cdot 4 \mathrm{H}_{2} \mathrm{O}$

\begin{tabular}{|c|c|c|c|c|c|}
\hline \multicolumn{2}{|c|}{ Pattern I } & \multicolumn{2}{|c|}{ Pattern 2} & \multirow[b]{2}{*}{$d \mathrm{cal}$} & \multirow[b]{2}{*}{$h k l$} \\
\hline$I / / \mathrm{o}$ & dobs & $I / / 0$ & dobs & & \\
\hline 20 & 6.414 & 20 & 6.362 & $6.387,6.378$ & 110,002 \\
\hline 70 & 5.748 & $\begin{array}{r}100 \\
5\end{array}$ & $\begin{array}{l}5.722 \\
5.366\end{array}$ & $5: 712$ & 111 \\
\hline \multirow[t]{2}{*}{30} & 4.522 & 40 & 4.519 & $4.517,4.513$ & 112,200 \\
\hline & & 5 & 4.253 & $4.257,4.252$ & 201,003 \\
\hline 10 & 3.695 & 20 & 3.690 & 3.686 & 202 \\
\hline 8 & 3.553 & $30 \mathrm{~b}$ & 3.548 & 3.539 & 113 \\
\hline 5 & 3.445 & & & 3.413 & 212 \\
\hline 20 & 3.198 & 60 & 3.192 & 3.194 & 220,004 \\
\hline 100 & 3.100 & 40 & 3.101 & 3.098 & 203,221 \\
\hline \multirow[t]{2}{*}{10} & 2.984 & 10 & 3.006 & 3.007 & 104 \\
\hline & & 5 & 2.924 & $2.930,2.928$ & 301,213 \\
\hline 40 & 2.847 & 50 & 2.858 & $2.855,2.853$ & 222,114 \\
\hline \multirow[t]{4}{*}{80} & 2.786 & 50 & 2.794 & 2.787 & 311 \\
\hline & & 10 & 2.718 & 2.725 & 302 \\
\hline & & $5 b$ & 2.614 & $2.606,2.605$ & 312,204 \\
\hline & & 10 & 2.556 & $2.553,2.551$ & 223,005 \\
\hline \multirow[t]{2}{*}{30} & 2.368 & 70 & 2.375 & $2.371,2.369$ & 313,115 \\
\hline & & $5 b$ & 2.338 & 2.331 & 322 \\
\hline 8 & 2.251 & 10 & 2.257 & $2.258,2.257$ & 224,400 \\
\hline 5 & 2.226 & 5 & 2.224 & 2.224 & 401,205 \\
\hline 15 & 2.124 & 30 & 2.130 & 2.126 & $006,314,402$ \\
\hline 7 & 2.100 & 5 & 2.104 & 2.100 & 331 \\
\hline \multirow[t]{4}{*}{100} & 2.017 & 50 & 2.022 & 2.017 & $420,332,116$ \\
\hline & & 5 & 1.992 & $1.994,1.993$ & $225,403,421$ \\
\hline & & 5 & 1.969 & 1.970 & 324 \\
\hline & & $20 \mathrm{~b}$ & 1.927 & $1.925,1.923$ & 442,206 \\
\hline \multirow[t]{3}{*}{5} & 1.902 & 30 & 1.907 & 1.903 & 333,315 \\
\hline & & 5 & 1.846 & 1.842 & 404 \\
\hline & & 10 & 1.775 & $1.771,1.770$ & $510,334,226$ \\
\hline \multirow[t]{10}{*}{5} & 1.752 & 10 & 1.754 & $1.754,1.752$ & 511,117 \\
\hline & & $10 \mathrm{~b}$ & 1.707 & $1.707,1.706$ & $424,316,512$ \\
\hline & & $10 \mathrm{~b}$ & 1.639 & 1.635 & 513,335 \\
\hline & & $5 b$ & 1.586 & $1.584,1.582$ & $441,425,227$ \\
\hline & & $10 \mathrm{vb}$ & 1.550 & $1.549,1.548$ & $514,442,530$ \\
\hline & & $10 \mathrm{~b}$ & 1.500 & $1.505,1.503$ & $208,336,532$ \\
\hline & & 20 & 1.467 & 1.465 & 426,602 \\
\hline & & $5 b$ & 1.458 & 1.455 & 515,533 \\
\hline & & $20 \mathrm{~b}$ & 1.429 & 1.428 & $228,444,620$ \\
\hline & & $2 \mathrm{~b}$ & 1.393 & & \\
\hline
\end{tabular}

standard deviations than the tetragonal cell. Comparison of the powder patterns of bariosincosite and synthetic $\mathrm{Ba}\left(\mathrm{VOPO}_{4}\right)_{2} \cdot 4 \mathrm{H}_{2} \mathrm{O}$ showed them to be almost indentical but the reflections for the synthetic monoclinic compound are somewhat broader than those for the mineral. This, taken in conjunction with the optical data, indicates that bariosincosite is probably tetragonal. The space group could not be unambiguously assigned but there are no reflections of the $h k 0$-type with $h+k=2 n+1$ in the powder pattern suggesting possible space groups $P 4 / n$ or $P 4 / n m m$, the latter having been determined for the parent compound, $\mathrm{VOPO}_{4} \cdot 2 \mathrm{H}_{2} \mathrm{O}$.

\section{Relationship to other minerals and compounds}

Bariosincosite is the barium analogue of sincosite, but there has long been some uncertainty about the stoichiometry and the symmetry of sincosite. Schaller (1924) gave the formula for sincosite as $\mathrm{CaO} \cdot \mathrm{V}_{2} \mathrm{O}_{4} \cdot \mathrm{P}_{2} \mathrm{O}_{5} \cdot 5 \mathrm{H}_{2} \mathrm{O}$ 
BARIOSINCOSITE, A NEW BA-V PHOSPHATE MINERAL

TABLE 2. (contd.)

\begin{tabular}{|c|c|c|c|c|}
\hline \multirow{2}{*}{$\begin{array}{l}\text { Pattern l } \\
\text { I/Io dobs }\end{array}$} & \multicolumn{2}{|c|}{ Pattern 2} & \multirow[b]{2}{*}{$d \mathrm{cal}$} & \multirow[b]{2}{*}{$h k l$} \\
\hline & $I / / \mathrm{o}$ & dobs & & \\
\hline & $5 b$ & 1.358 & & \\
\hline & $10 \mathrm{~b}$ & 1.305 & & \\
\hline & $30 \mathrm{~b}$ & 1.272 & & \\
\hline & $10 \mathrm{~b}$ & 1.253 & & \\
\hline & $5 b$ & 1.229 & & \\
\hline & $2 b$ & 1.182 & & \\
\hline & $2 b$ & 1.165 & & \\
\hline & $20 \mathrm{~b}$ & 1.143 & & \\
\hline & $2 b$ & 1.128 & & \\
\hline & $5 b$ & 1.112 & & \\
\hline & $5 b$ & 1.094 & & \\
\hline & $10 \mathrm{~b}$ & 1.080 & & \\
\hline & $5 b$ & 1.065 & & \\
\hline & $5 b$ & 1.049 & & \\
\hline
\end{tabular}

Intensities visually estimated for both patterns.

Pattern 1 was recorded using a Guinier-Hägg camera using $\mathrm{Cr}-K \alpha_{1}$ radiation and $\mathrm{Si}$ as an internal standard.

Pattern 2 was recorded using a $114.6 \mathrm{~mm}$ Gandolfi camera with $\mathrm{Co}-K \alpha$ radiation on a polycrystalline sample. $\mathrm{b}=$ broad, $\mathrm{vb}=$ very broad.

(i.e. $\mathrm{Ca}\left(\mathrm{VOPO}_{4}\right)_{2} \cdot 5 \mathrm{H}_{2} \mathrm{O}$ ), although chemical data on another one of his samples indicates 4 rather than $5 \mathrm{H}_{2} \mathrm{O}$. Zolensky (1985) recorded a full powder diffraction pattern for sincosite, indexed by analogy to the meta-autunite cell, but assumed the composition to be a $\left(\mathrm{VOPO}_{4}\right)_{2} \cdot 5 \mathrm{H}_{2} \mathrm{O}$. Shitov et al. (1984) reported sincosite from Kazakhstan and showed that the mineral contains only $4 \mathrm{H}_{2} \mathrm{O}$. They also found the mineral to be biaxial negative with $\alpha 1.670, \beta$ $1.690, \gamma 1.694$ but with pseudotetragonal symmetry, $a=9.08, c 12.86 \AA$ and proposed the space group $P 4_{2} / n$. Kang et al. (1992) prepared $\mathrm{Ca}\left(\mathrm{VOPO}_{4}\right)_{2} \cdot 4 \mathrm{H}_{2} \mathrm{O}$ via hydrothermal methods and determined the crystal structure They found $\mathrm{Ca}\left(\mathrm{VOPO}_{4}\right)_{2} \cdot 4 \mathrm{H}_{2} \mathrm{O}$ to be triclinic $P 1$, with $a=6.3484, b=6.350, c=6.597 \AA$; $\alpha=106.81^{\circ}, \beta=94.09^{\circ}, \gamma=90.02^{\circ}$. They also noted a second reaction product, $\mathrm{Ca}_{x}\left(\mathrm{VOPO}_{4}\right)_{2} \cdot 4 \mathrm{H}_{2} \mathrm{O}$ with $x<1$ which was a darker shade of green and crystallized in Pnma. Kang et al. (1992) reported that a comparison of the calculated powder pattern of their synthetic calcium compound to that of sincosite reported by Zolensky (1985) indicates that the crystal structures are similar and that the naturally occurring mineral has higher symmetry. Franke et al. (1997) also synthesized $\mathrm{Ca}\left(\mathrm{VOPO}_{4}\right)_{2} \cdot 4 \mathrm{H}_{2} \mathrm{O}$ by hydrothermal methods and checked the identity of the product by X-ray powder diffraction. Single crystal structure analysis of their product also showed only $4 \mathrm{H}_{2} \mathrm{O}$ per formula unit and triclinic symmetry, but with a strong pseudotetragonal cell (Franke et al., 1997).

Roca et al. (1997) noted that there is a large family of layered oxovanadium phosphate hydrates, of the type $\mathrm{M}\left(\mathrm{VOPO}_{4}\right)_{2} \cdot n \mathrm{H}_{2} \mathrm{O}$ ( $M=$ metal cation). Some of these compounds are employed as catalysts, while others have unusual magnetic interactions and ion exchange behaviour (Ayyappan et al., 1998). The layered vanadium phosphates are also closely related to the layered niobium and zirconium phosphates $\left(\mathrm{NbOPO}_{4}\right.$ and $\left.\mathrm{ZrOPO}_{4}\right)$ which are the subject of considerable interest because of their significant negative thermal expansion (Sleight, 1998).

The following oxovanadium phosphate hydrates have been reported: $\mathrm{M}\left(\mathrm{VOPO}_{4}\right)_{2} \cdot n \mathrm{H}_{2} \mathrm{O}$, $M=\mathrm{Na}, \mathrm{Ca}, \mathrm{Sr}, \mathrm{Ba}, \mathrm{Pb}, \mathrm{Co}, \mathrm{Ni}, \mathrm{Cu}, \mathrm{Ag}$, all have $n=4 ; M=\mathrm{K}, \mathrm{Rb}, \mathrm{Pb}, \mathrm{Ni}$, all have $n=3$; $M=\mathrm{Cu}, \mathrm{Zn}$ but with very low stoichiometry $x=0.1$ to 0.2 , have $n=5$ (Kang et al., 1992, Roca et al., 1997, Ayyappan et al., 1998). The parent compound, $\mathrm{VOPO}_{4} \cdot 2 \mathrm{H}_{2} \mathrm{O}$, has the same $\mathrm{VOPO}_{4}$ layer as sincosite and bariosincosite and is tetragonal, $P 4 / \mathrm{nmm}, a=6.202, c=7.710 \AA$. 


\section{A. PRING ETAL}

The layers consist of alternating $\mathrm{V}\left(\mathrm{O}, \mathrm{H}_{2} \mathrm{O}\right)_{6}$ octahedra and $\mathrm{PO}_{4}$ tetrahedra linked via corners and are joined via $\mathrm{H}$ bonding or interlamellar cations (Fig. 2). Kang et al. (1992) noted that the insertion of interlamellar cations results in the relative displacement of adjacent $\mathrm{VOPO}_{4}$ layers, the nature of the displacement varying between compounds; in $\mathrm{Ca}\left(\mathrm{VOPO}_{4}\right)_{2} \cdot 4 \mathrm{H}_{2} \mathrm{O}$ the layers are displaced by $a / 2$.

There must remain some doubt about the actual symmetry of bariosincosite and since there is no definitive evidence to suggest a lower symmetry, convention has been followed here and the unit cell with the highest symmetry has been chosen. Given the layered nature of these structures it seems likely that a number of polytypes may exist in nature, their occurrence being controlled by cation stoichiometry and conditions of crystallization.

Roca et al. (1997) prepared $\mathrm{Ba}\left(\mathrm{VOPO}_{4}\right)_{2} \cdot 4 \mathrm{H}_{2} \mathrm{O}$ (Fig. 2) by reacting $\mathrm{V}$ metal, $\mathrm{V}_{2} \mathrm{O}_{5}$, $\mathrm{Ba}\left(\mathrm{CH}_{3} \mathrm{COO}\right)_{2}, \mathrm{H}_{3} \mathrm{PO}_{4}$ and water in a teflon acid digestion hydrothermal bomb at $200^{\circ} \mathrm{C}$ for $48 \mathrm{~h}$. The other members of the structural family have been prepared hydrothermally, under acidic conditions (pH 1-2) (Kang et al., 1992; Roca et al., 1997; Ayyappan et al., 1998) or via direct redox intercalation reactions of $\mathrm{VOPO}_{4} \cdot 2 \mathrm{H}_{2} \mathrm{O}$ in metal iodide solutions (Jacobson et al.,1985). At the Spring Creek Mine milder conditions of formation are indicated and supergene or low temperature late-stage hydrothermal conditions are probable. The close association with cuprite and native copper indicates a slightly oxidizing or neutral environment (Williams, 1990) and it is possible that under these conditions the $\left(\mathrm{VOPO}_{4}\right)$ layers in $\mathrm{Ba}\left(\mathrm{VOPO}_{4}\right)_{2} \cdot 4 \mathrm{H}_{2} \mathrm{O}$ stack to give a tetragonal structure.

\section{Acknowledgements}

Thanks are due to Stuart McClure of CSIRO Division of Land and Water, Adelaide for the SEM photomicrograph. We thank the South Australian Department of Environment, Heritage and Aboriginal Affairs for granting a permit to collect further material at the Spring Creek Mine.
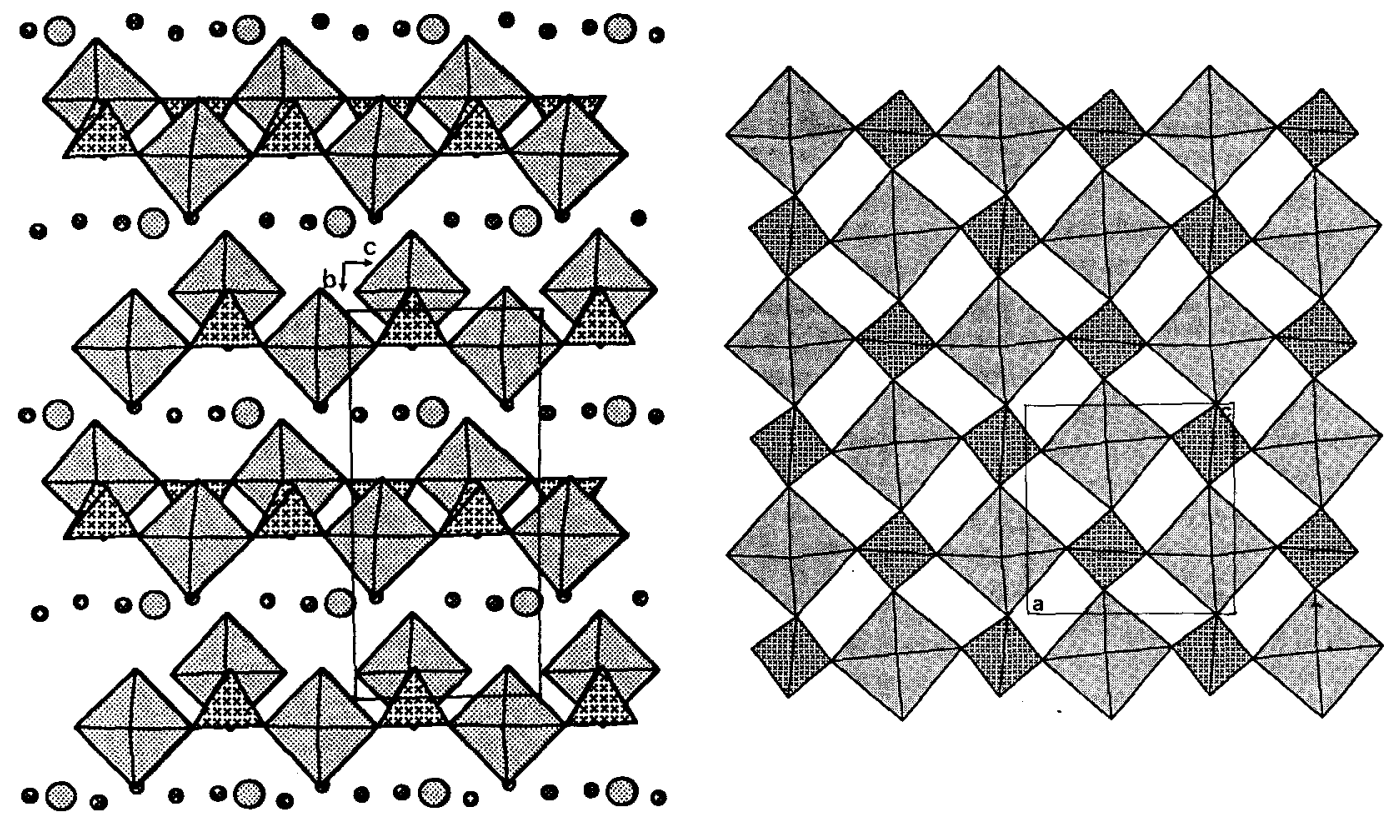

FIG. 2. The structure of synthetic monoclinic $\mathrm{Ba}\left(\mathrm{VOPO}_{4}\right)_{2} \cdot 4 \mathrm{H}_{2} \mathrm{O}$. (a) View down $\{100\}$ showing the VOPO4 layers and the arrangement of interlayer Ba ions (large circles) and water molecules (small circles) $(b)\{010\}$ view of the $\mathrm{VOPO}_{4}$ layers with Ba cations and water molecules omitted (after Roca et al., 1997). 


\section{.BARIOSINCOSITE, A NEW BA-V PHOSPHATE MINERAL}

\section{References}

Austin, J.B. (1863) The Mines of South Australia. Platts, Wigg, Dehane, Howell, Rigby and Mullet, Adelaide, pp. 27-28.

Ayyappan, P., Ramanan, A. and Torardi, C.C. (1998) New metal-intercalate layered vanadyl phosphates, $\mathrm{M}_{\mathrm{x}} \mathrm{VOPO}_{4} \cdot \mathrm{yH}_{2} \mathrm{O}(\mathrm{M}=\mathrm{Ag}, \mathrm{Cu}, \mathrm{Zn})$. Inorg. Chem., 37, 3628-34.

Beyer, B. D. and Elliott, P. (1996) Minerals from the Spring Creek mine, near Wilmington, South Australia. Aust. J. Mineral., 2, 57-70.

Binks, P.J., Forbes, B.G. and Mirams, R.C., (1968) Geol. Surv. South Aust, Orroroo sheet, S 54-1 1:250,000.

Birch, W.D. and Mumme, W.G. (1988) Hentschelite and perloffite from Spring Creek Copper Mine, South Australia. Mineral. Mag., 52, 408-11.

Franke, W.A., Luger, P., Weber, M. and Ivanova, T.I. (1997) Hydrothermal growth of sincosite. Proc. Russian Mineral. Soc., 126, 85-6.

Jaccobson, A.J., Johnson, J.W., Brody, J.F., Scanlon, J.C. and Lewandowski, J.T. (1985) Redox intercalation reactions of $\mathrm{VOPO}_{4} .2 \mathrm{H}_{2} \mathrm{O}$ with mono- and divalent cations. Inorg. Chem., 24, 1782-7.

Jack, R.L. (1917) Unpulished report to Royal Commission on Water Supply, South Australian Department of Mines and Energy, Records Branch Docket No. 1069/16.

Kang, H.W., Lee, W.C., Wang S.L. and Lii, K.H. (1992) Hydrothermal synthesis and structural charaterization of four layered vanadyl(IV) phosphate hydrates $\mathrm{A}(\mathrm{VO})_{2}\left(\mathrm{PO}_{4}\right)_{2} \cdot 4 \mathrm{H}_{2} \mathrm{O}(\mathrm{A}=\mathrm{Co}, \mathrm{Ca}, \mathrm{Sr}, \mathrm{Pb})$. Inorg. Chem., 31, 4743-8.

Kolitsch, U., Pring, A., Taylor, M.R. and Fallon, G.
(1999) Springcreekite, $\mathrm{Ba}\left(\mathrm{V}^{3+}, \mathrm{Fe}\right)_{3}\left(\mathrm{PO}_{4}\right)_{2}$ $\left(\mathrm{OH}, \mathrm{H}_{2} \mathrm{O}\right)_{6}$ a new member of the crandallite group, from the Spring Creek Mine, South Australia: the first natural $\mathrm{V}^{3+}$ member of the alunite family and its crystal structure. Neues Jahrb. Min. Mh. (in press).

Preiss, W. (1987) The Adelaide Geosyncline: Late Proterozoic stratigraphy, sedimentation palaeontology and tectonics. South Aust. Mines Energy Bull., 53, $180-1$.

Roca, M., Marcos, M.D., Amorós, P., Alamo, J., Beltrán-Porter, A. and Beltrán-Porter, D. (1997) Synthesis and crystal structure of a novel lamellar barium derivative: $\mathrm{Ba}\left(\mathrm{VOPO}_{4}\right)_{2} \cdot 4 \mathrm{H}_{2} \mathrm{O}$. Synthetic pathways for layered oxovanadium phosphate hydrates $\mathrm{M}\left(\mathrm{VOPO}_{4}\right)_{2} \cdot \mathrm{nH}_{2} \mathrm{O}$. Inorg. Chem., 36, 3414-21.

Schaller, W.T. (1924) The occurrence and properties of sincosite, a new vanadium mineral from Sincos, Peru. Amer. J. Sci., series 8, 48, 462.

Shitov, V.A., Prozorovsky, E.V., Smyslova, I.G. and Kuznetsova, L.G. (1984) Sincosite - rare vanadium calcium phosphate. Zap. Vses. Mineral. Obsh., 113, 56-9.

Sleight, A.W. (1998) Compounds that contract on heating. Inorg. Chem., 37, 2854-60.

Summers, K.W.A. (1953) Spring Creek Copper Mine, South Aust. Mines, Mining Review, No. 98, 130-2.

Williams, P.A. (1990) Oxidized Zone Geochemistry. Ellis Horwood, New York.

Zolensky, M.E. (1985) New data on sincosite. Amer. Mineral., 70, 409-10.

[Manuscript received 12 October 1998:

revised 6 January 1999] 